\title{
Adaptability of Macrophomina phaseolina, the Incident of Stem and Root Rot Disease of Sesame to Different Regime of Temperature, pH and Light Period
}

\author{
B. Khamari*, S.N. Satapathy, S. Roy and C. Patra \\ Institute of Agricultural Sciences, SoA, Bhubaneswar, Odisha, India \\ *Corresponding author
}

A B S T R A C T

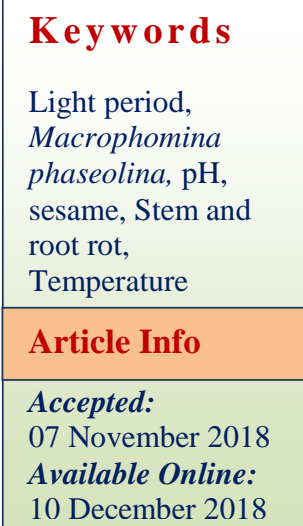

\section{Introduction}

Sesame is an oldest oilseed crop grown in hotter and drier areas of world. It is known as queen of oil seed because of its elite quality, good storage and keeping quality as well as high oil content. Being a short duration, drought tolerant crop, it is adapted to a wide range of cropping situations. It is mostly grown in Asian and African countries. In India, it is mostly grown in western, southern and eastern part. India produced 870 thousand metric tons in fiscal year 2015-2016 with productivity of $413 \mathrm{~kg} / \mathrm{ha}$ (Annual report, 2016-17). It is generally grown in almost all districts of Odisha, mainly in Ganjam, Angul,
Sundergarh, Dhenkanal, Raygada, Subarnapur, Bargarh and Bolangir. In Odisha, sesame is generally grown in drier areas, with light textured, less fertile soil in rainfed condition. Irrespective of its wide adaptability and productions, there are many constraints which reduce the productivity of sesame. Stem and root rot disease is an important biotic constraint causing huge economic loss. Macrophomina phaseolina, the incitant of stem and root rot disease is a soil borne, polyphagous fungus with heterogenous host specificity. Incidence and development of disease are favored under high temperature and drought stresses conditions (Abawi and Pastor-Corrales, 1990). Therefore, the present 
investigation was carried out to critically study the effect of physiological parameters like $\mathrm{pH}$, temperature and duration of light on growth of Macrophomina phaseolina in vitro.

\section{Materials and Methods}

\section{Pathogen culture}

The pathogen inciting stem and root rot disease was isolated from diseased plant sample and identified as Macrophomina phaseolina which was further confirmed by ITCC, IARI, New Delhi with ID No. 9811.15. Pathogen was grown in potato dextrose agar media and 7days old fresh culture was used for the studies.

Effect of hydrogen ion concentration on mycelial growth of test fungus

In order to study best $\mathrm{pH}$ for mycelial growth of test fungus, it was tested in a range of $\mathrm{pH}$ from 3 to 10. For the experiment, Fifty $\mathrm{ml}$ of potato dextrose broth was poured in $100 \mathrm{ml}$ capacity conical flasks. The $\mathrm{pH}$ of potato dextrose broth was adjusted to various ranges from 3 to 10 by using $\mathrm{pH}$ meter adding standard $0.5 \mathrm{M} \mathrm{NaOH}$ or $0.5 \mathrm{M} \mathrm{HCl}$. All the flasks were inoculated with $5 \mathrm{~mm}$ agar discs and incubated at $28 \pm 1^{\circ} \mathrm{C}$. Three replications were maintained for each $\mathrm{pH}$ value. The experiment was laid in completely randomized block design. After five days of inoculation, it was filtered through whatman no 1 filter paper and mycelial mat were collected. These mycelial mat were dried in hot air oven at $60^{\circ} \mathrm{C}$ for 2 hours. Dry weight of the mycelial mat was recorded. The data obtained were statistically analysed.

Response of different temperature regimes on Macrophomina phaseolina

In order to determine the optimum temperature required for radial growth the fungus, a $5 \mathrm{~mm}$ mycelial disc was transferred to potato dextrose agar medium in petriplates and incubated at temperature of $5^{\circ} \mathrm{C}, 10^{\circ} \mathrm{C}$, $15^{\circ} \mathrm{C}, 20^{\circ} \mathrm{C}, 25^{\circ} \mathrm{C}, 30^{\circ} \mathrm{C}, 35^{\circ} \mathrm{C}, 40^{\circ} \mathrm{C}, 45^{\circ} \mathrm{C}$ and $50^{\circ} \mathrm{C}$ in triplicates following completely randomized design. After 5 days of incubation, the diameter of the fungal colonies was measured and the data obtained were statistically analysed.

Effect of light period on radial growth of $M$. phaseolina

To know the effect of light on growth and sporulation of $M$. phaseolina, the experiment was undertaken. A $5 \mathrm{~mm}$ mycelial disc was transferred to petriplates containing potato dextrose agar medium. These plates were incubated at different duration of light such as 24hours light, 24 hours dark, 12 hours light and 12 hours dark, 16 hours light and 8 hours dark and 8 hours dark and 16 hours light. The radial growth was measured on $3^{\text {rd }}$ and $5^{\text {th }}$ day of inoculation.

\section{Results and Discussion}

Effect of hydrogen ion concentration ( $\mathrm{pH}$ ) on fungal biomass of Macrophomina phaseolina in vitro

Variation in $M$. phaseolina biomass accumulation was recorded due to change in hydrogen ion concentration. It was revealed that the fungus could grow over a wide range of $\mathrm{pH}$ from 3.0 to 10.0. Maximum biomass accumulation was observed at $\mathrm{pH} 6.5$ (285.8 $\mathrm{mg}$ ) followed by $\mathrm{pH} 7(278.0 \mathrm{mg})$ and $\mathrm{pH} 6.0$ $(275.25 \mathrm{mg})$ which were at par. The minimum mycelial growth was observed at $\mathrm{pH}$ $3.0(196.00 \mathrm{mg})$. Mean dry mycelial weight in the range of $\mathrm{pH}$ 6.0-7.0 clearly indicated the preference of pathogen to grow vigorously. The growth of mycelium reduces as the $\mathrm{pH}$ increases or decreases. Neutral range of $\mathrm{pH}$ is ideal for growth of Macrophomina phaseolina (Table 1). 
Response of different temperature regimes on Macrophomina phaseolina

The pathogen grew in a wide range of temperature from $15^{\circ} \mathrm{C}$ to $50^{\circ} \mathrm{C}$. The maximum radial growth was found at temperature of $35^{0} \mathrm{C}(90.00 \mathrm{~mm})$ which is at par with temperature regime of $30^{\circ} \mathrm{C}$ $(85.7 \mathrm{~mm})$. The next best in the order of merit is $40^{\circ} \mathrm{C}$ followed by $45^{\circ} \mathrm{C}$.

Lowest mycelia growth was registered at $15^{\circ} \mathrm{C}$. No growth was recorded at temperature $5^{\circ} \mathrm{C}$ and $10^{\circ} \mathrm{C}$. From the experiment it is seen that, maximum mycelial growth of $M$. phaseolina was recorded at $35^{\circ} \mathrm{C}$ followed by $30^{\circ} \mathrm{C}$ while no growth was found at lower temperatures i.e., $5^{0} \mathrm{C}$ and $10^{\circ} \mathrm{C}$. The radial growth reduced as the temperature increased as well as decreased. The table 2 clearly indicates the pathogen preference towards higher temperature.

\section{Effect of duration of light on radial growth of Macrophomina phaseolina}

Exposure to different light period has great influence on radial diameter of pathogen. It is revealed from table 3 that maximum growth was registered at 12 hours light and 12 hours dark $(4.55 \mathrm{~cm})$ followed by 16 hours light and 8 hours dark $(4.20 \mathrm{~cm})$ at $3^{\text {rd }}$ day of inoculation. There was no significant difference in radial growth of pathogen when exposed to different duration of light. At $5^{\text {th }}$ day, maximum radial growth of pathogen was observed at 12 hours light and 12 hours dark $(7.69 \mathrm{~cm})$ followed by 8 hours light and 16 hours dark $(7.67 \mathrm{~cm})$ and 16 hours light and 8 hours dark $(7.48 \mathrm{~cm})$ which were at par.

The pathogen prefers $\mathrm{pH}$ range from 6 to 7 . Similar findings do exist in literature. Csöndes et al., (2012) observed the most favourable temperature regimes ranged between 25 and $35^{\circ} \mathrm{C}$ and optimal $\mathrm{pH}$ for the pathogen varied between 4.0 and 6.0 .
Sukanya et al., (2016) found the maximum growth of M. phaseolina causing charcoal rot of sorghum was observed at $35^{\circ} \mathrm{C}$ after $72 \mathrm{hrs}$ of incubation and at $\mathrm{pH}$ of 6.0. Kulkarni (2000), Bhupathi and Theradimani (2018) and Chowdary and Govindaiah (2007) found highest growth of macrophomina at neutral $\mathrm{pH}$ i.e. 7.0 affecting maize, blackgram and mulberry respectively). Kaur et al., (2013) observed higher relative growth rate at $30^{\circ} \mathrm{C}$ followed by $35^{\circ} \mathrm{C}$ and higher mean dry mycelial weight at $\mathrm{pH} 6$ and 7. These findings of earlier authors are in line of conformity to present finding.

The optimum temperature for growth of pathogen is $35^{\circ} \mathrm{C}$ followed by $30^{\circ} \mathrm{C}$. Similar findings were also observed by earlier workers. Yang and Navi (2003) found soil temperature of $80-95^{\circ} \mathrm{F}\left(27-35^{\circ} \mathrm{C}\right)$ for 2 to 3 weeks favoured disease development. Cardona (2006) reported ideal temperature for the fungus is $28-32^{\circ} \mathrm{C}$.

Csöndes et al., (2007) stated 25 to $35^{\circ} \mathrm{C}$ would be the most favourable temperature regime for Macrophomina phaseolina and very slow mycelial growth at 10,15 and $40^{\circ} \mathrm{C}$ where there was no microsclerotia formation. Akhtar et al., (2011) opined $30-35{ }^{\circ} \mathrm{C}$ is optimum for fungal growth and microsclerotia production. Thus, the present finding derived ample support from earlier workers.

Deepthi et al., (2014) showed the mycelial growth of M. phaseolina varied with varying colours of light and length of light period but there was no significant difference in the growth and biomass production of $M$. phaseolina. Muthukrishnan et al., (1995) noticed that continuous light or light alternated with dark favored the growth of Rhizoctonia from pulses in vitro on Czapeck's Dox liquid medium. Veerendra Kumar (2004) showed the effect of alternate light and darkness on good growth and sclerotia formation as compared to continuous light and continuous darkness. 
Manjunatha and Naik (2011) recorded continuous light (71.89) and continuous maximum colony diameter of $R$. bataticola when cultures were exposed to alternate cycles of light and darkness (73.28) followed by darkness (68.64). These statements of earlier worker corroborate our present finding.

Table.1 Effect of $\mathrm{pH}$ on fungal biomass of Macrophomina phaseolina in vitro

\begin{tabular}{|c|c|c|}
\hline SI. No & pH & Dry mycelia weight(mg) \\
\hline 1 & 3.0 & 196.00 \\
\hline 2 & 3.5 & 197.00 \\
\hline 3 & 4.0 & 204.00 \\
\hline 4 & 4.5 & 226.50 \\
\hline 5 & 5.0 & 230.00 \\
\hline 6 & 5.5 & 238.00 \\
\hline 7 & 6.0 & 275.25 \\
\hline 8 & 6.5 & 285.80 \\
\hline 9 & 7.0 & 278.00 \\
\hline 10 & 7.5 & 260.00 \\
\hline 11 & 8.0 & 257.00 \\
\hline 12 & 8.5 & 246.00 \\
\hline 13 & 9.0 & 240.25 \\
\hline 14 & 9.5 & 217.00 \\
\hline 15 & 10.0 & 210.00 \\
\hline \multicolumn{2}{|c|}{$\begin{array}{l}\mathrm{SE}(\mathrm{m}) \pm \\
\mathrm{CD}(0.05)\end{array}$} & $\begin{array}{l}14.957 \\
45.495\end{array}$ \\
\hline
\end{tabular}

Table.2 Temperature response of Macrophomina phaseolina in vitro

\begin{tabular}{|c|c|c|}
\hline SI no. & $\begin{array}{l}\text { Temperature } \\
\left({ }^{0} \mathrm{C}\right)\end{array}$ & Mean $(\mathrm{mm})$ \\
\hline $\mathbf{1}$ & 5 & 0.00 \\
\hline 2 & 10 & 0.00 \\
\hline 3 & 15 & 0.70 \\
\hline 4 & 20 & 4.57 \\
\hline 5 & 25 & 4.90 \\
\hline 6 & 30 & 8.57 \\
\hline 7 & 35 & 9.00 \\
\hline $\mathbf{8}$ & 40 & 7.80 \\
\hline 9 & 45 & 7.23 \\
\hline $\mathbf{1 0}$ & 50 & 5.83 \\
\hline $\mathrm{CD}(0.05)$ & & 0.567 \\
$\mathrm{SE}(\mathbf{m}) \pm$ & & 0.191 \\
\hline
\end{tabular}


Table.3 Effect of light period on mycelia growth of M. phaseolina

\begin{tabular}{|c|c|c|c|}
\hline \multirow[t]{2}{*}{ SI no } & \multirow[t]{2}{*}{ Treatments } & \multicolumn{2}{|c|}{ Radial diameter } \\
\hline & & $\begin{array}{l}3^{\text {rd }} \text { day of } \\
\text { inoculation }\end{array}$ & $\begin{array}{l}5^{\text {th }} \text { day of } \\
\text { inoculation }\end{array}$ \\
\hline 1 & 24 hours light & 3.98 & 7.34 \\
\hline 2 & 24 hours dark & 3.89 & 5.54 \\
\hline 3 & 12 hours light and 12 hours dark & 4.55 & 7.69 \\
\hline 4 & 16 hours light and 8 hours dark & 4.20 & 7.48 \\
\hline 5 & 8 hours light and 16 hours dark & 3.73 & 7.67 \\
\hline \multicolumn{2}{|c|}{$\begin{array}{l}\mathrm{SE}(\mathrm{m}) \pm \\
\mathrm{CD}\end{array}$} & $\begin{array}{c}0.369 \\
\text { N.S. }\end{array}$ & $\begin{array}{l}0.212 \\
0.645\end{array}$ \\
\hline
\end{tabular}

The studies revealed that temperature, $\mathrm{pH}$ and light period influences the growth of the fungi. These in vitro studies are preliminary work which gave an idea about the optimum condition for growth of pathogen. Further study in field should be done in natural weather condition which will provide more information about relationship between abiotic factors with the disease incidence.

\section{References}

Abawi, G.S. and Corrales, M.A.P., 1990. Root rots of beans in Latin America and Africa: Diagnosis, Research Methodologies and Management Strategies. CIAT, Cali, Colombia.

Akhtar, K.P., Sarwar, G. and Arshad, H.M.I. 2011. Temperature response, pathogenicity, seed infection and mutant evaluation against Macrophomina phaseolina causing charcoal rot disease of sesame. Archives of Phytopathology and Plant Protection, 44(4): 320-330.

Annual report, 2016-17, Department of Agriculture, Cooperation \& Farmers Welfare Ministry of Agriculture \& Farmers Welfare Government of India.

Bhupathi, P. and Theradimani, M. (2018) In vitro Studies of carbon, Nitrogen sources and $\mathrm{pH}$ on mycelia growth Blackgram Root rot caused by
Macrophomina phaseolina. The Pharma Innovation Journal, 7(6): 33-35

Chowdary NB, Govindaiah. (2007) Influence of different abiotic conditions on the growth and sclerotial production of Macrophomina phaseolina. Indian Journal of Sericulture. 46:186-188.

Csöndes, I., Kadlicskó, S. and Gáborjányi, R. 2007. Effect of different temperature and culture media on the growth of Macrophomina phaseolina. Commun Agric Appl Biol Sci.72(4):839-48.

Csöndes I, Cseh A, Taller J, Poczai P. 2012. Genetic diversity and effect of temperature and $\mathrm{pH}$ on the growth of Macrophomina phaseolina isolates from sunflower fields in Hungary. Mol Biol Rep.,39(3):3259-69.

Deepthi, P. Reddy, S.S., Shuklal, S. and Verma, K. P. 2014. Effect of Physiological Factors on Growth and Biomass of Macrophomina phaseolina. Agrica,3:14-18.

Kaur Surinder, Chauhan Vijay Bahadur, Brar Satinder Kaur and Dhillon Gurpreet Singh. (2013) Int. J. of Life Sciences, 1 (2): $81-88$

Kulkarni, S., 2000, Biology and management of dry stalk rots of maize (Zea mays L.) caused by Fusarium moniliformae (Sheild) and Macrophomina phaseolina (Tassi) Goid. Ph.D. Thesis, Univ. Agric. Sci., Dharwad, pp.160-164. 
Manjunatha, S. V. and Naik, M. K., 2011, Morphological diversity in isolates of Rhizoctonia bataticola causing dry root rot of chickpea. J. Mycol. Pl. Pathol., 41(2): 279-281.

Muthukrishnan, K., Arjunan, G. and Raguchander, T., 1995, Some pathological studies on Macrophomina phaseolina root rot of urdbean. Indian J. Pulse Res., 8(2): 162-165.

Sukanya R., Jayalakshmi S.K. and Girish G.2016. Effect of temperature and $\mathrm{pH}$ levels on growth of Macrophomina phaseolina (tassi) goid. Infecting sorghum. International Journal of Agriculture Sciences, 8(37): 1768-1770.

Veerendra Kumar, K. V., 2004, Studies on dry root rot disease of chickpea caused by $R$. bataticola. M. Sc. Thesis, Univ. Agric. Sci., Dharwad (India), p. 95.

Yang, X.B. and Navi, S 2003. Charcoal RotA dry weather disease. Integrated Crop Management, 22:166-16.

\section{How to cite this article:}

Khamari, B., S.N. Satapathy, S. Roy and Patra, C. 2018. Adaptability of Macrophomina phaseolina, the Incident of Stem and Root Rot Disease of Sesame to Different Regime of Temperature, $\mathrm{pH}$ and Light Period. Int.J.Curr.Microbiol.App.Sci. 7(12): 761-766. doi: https://doi.org/10.20546/ijcmas.2018.712.094 